\title{
Besar Sudut Potongan Pada Balok Baja Castella Beam Terhadap Optimalisasi Tegangan Lentur
}

\author{
Berkat Cipta Zega ${ }^{1}$, M. Imaduddin ${ }^{1}$, Hakas Prayuda ${ }^{2}$ \\ ${ }^{1}$ Jurusan Teknik Sipil, Fakultas Teknik, Universitas Negeri Surabaya \\ 2 Jurusan Teknik Sipil, Fakultas Teknik, Universitas Muhammadiyah Yogyakarta \\ Email: zegaeka06@gmail.com
}

\begin{abstract}
ABSTRAK
Penggunaan baja dalam konstruksi bangunan akhir-akhir ini semakin meningkat. Bahkan baja merupakan material pokok dalam sebuah struktur bangunan. Baja bisa digunakan sebagai balok, kolom, dan konstruksi atap. Dengan semakin banyaknya pengguna baja dalam konstruksi bangunan, maka semakin banyak juga jenis dan bentuk yang ditawarkan oleh pasar. Salah satunya adalah balok yang terbuat dari baja yaitu balok Castella Beam. Penelitian ini bertujuan untuk mengatahui optimalisasi tegangan lentur berdasarkan kuat lenturnya dengan mengubah besar sudut potongannya (Ø). Hasil penelitian menunjukkan bahwa dengan adanya penambahan besar sudut pemotongan profil pada balok kastela ada indikasi terjadi kerusakan geser pada penampang balok yang berlubang. Jika besar sudut pemotongan profil lebih dari $40^{\circ}$, ada indikasi terjadi rusak geser pada penampang balok yang berlubang, akan tetapi pada besar sudut pemotongan profil kurang dari $40^{\circ}$ mengalami pergoyangan (buckling) yang paling besar, dan momen, tegangan serta lendutan yang terjadi paling kecil. Ditinjau dari momen, tegangan, lendutan, dan pergoyangan (buckling) maka besar sudut pemotongan profil mulai dari $50^{\circ}$ adalah profil yang memenuhi syarat, akan tetapi pada keadaan ini lemah terhadap gaya geser.
\end{abstract}

Kata Kunci : Castella Beam, tegangan lentur, besar sudut potongan (Ø),gaya geser, momen, tegangan, lendutan, dan pergoyangan (buckling)

\section{PENDAHULUAN}

Balok Castella Beam adalah balok yang dipakai untuk konstruksi bentang panjang lebih dari 10 meter. Balok ini berasal dari 1 profil baja yang kemudian dipotong dan disatukan kembali untuk mendapatkan tinggi profil yang sesuai, seperti terlihat pada Gambar 1. Bagian web yang dipotong dengan pola Castella disambungkan dengan cara las. Dengan memodifikasi profil ini maka tinggi profil menjadi 2 kali dari tinggi profil aslinya. Hasil dari potongan profil yang disatukan akan membentuk lubang segi enam, seperti pada Gambar 2. Profil tersebut dilubangi untuk memperkecil berat sendiri profil.
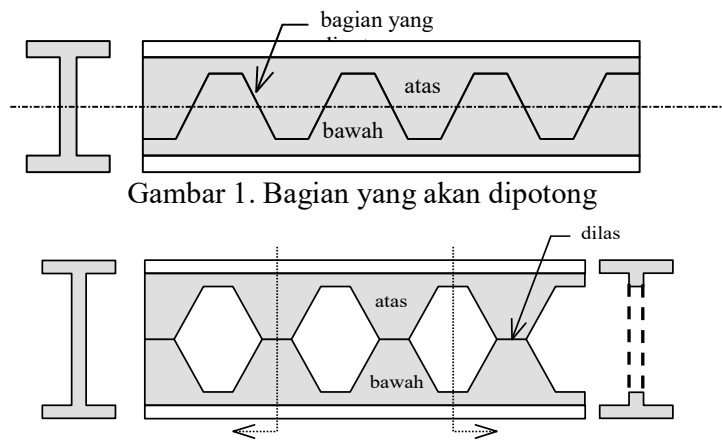

Gambar 2. Hasil penggabungan pemotongan.
Besarnya sudut kemiringan $\varnothing$ adalah antara $45^{\circ}$ sampai $70^{\circ}$. Yang sering dipakai di lapangan adalah sudut $45^{\circ}$ dan $60^{\circ}$. Sudut $\varnothing$ ditentukan dengan memperhitungkan tegangan geser pada bagian garis netral badan sehingga tidak melebihi tegangan ijinnya.

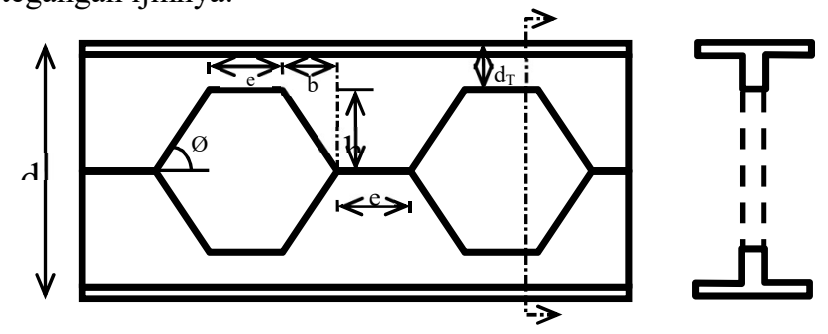

Gambar 3. Sudut kemiringan $\Theta$ dari gambar di atas didapat persamaan:

$$
\begin{gathered}
\tan \emptyset=\frac{h}{t} \quad \text { atau } \quad b=\frac{h}{\tan \varnothing} \\
d_{g}=d_{b}+h \quad \text { atau } \quad d_{T}=\frac{d_{b}-h}{2} \\
s=2(b+e)
\end{gathered}
$$

dengan :

$\mathrm{d}_{\mathrm{g}} \quad=$ tinggi profil castella .

$\mathrm{d}_{\mathrm{b}}=$ tinggi profil balok awal.

$\mathrm{h}=$ tinggi pemotongan profil. 
Dari semua uraian di atas belum disebutkan adanya pengaruh besar sudut potongan profil $(\varnothing)$ terhadap tegangan, oleh sebab itu penulis berencana untuk melakukan eksperimen untuk mengetahui optimalisasi tegangan lentur balok castella terkait besar dudut potongan profil (Ø) ditinjau dari uji lendutan. Dengan kontrol optimalisasi pada uji lendutan:

$$
\Delta_{\text {maksimum }}=\frac{L}{240}
$$

\section{METODE PENELITIAN}

Jenis penelitian ini adalah penelitian eksperimen, penelitian yang menggunakan profil baja sebagai bahan utama dalam penelitian. Dalam penelitian ini profil baja yang digunakan adalah profil baja berukuran WF 198.99.4,5.7.

Proses eksperimennya adalah profil baja WF 198.99.4,5.7 dibuat menjadi baja castella beam yaitu dengan membuat pola yang kemudian dibentuk dengan cara membelah bagian tengah pelat badan sesuai pola, kemudian bagian bawah dari belahan tersebut dibalik dan disatukan kembali antara bagian atas dan bawah dengan cara digeser sedikit kemudian dilas.

Pada eksperimen ini akan dibuat tujuh benda uji baja castella beam dengan ukuran panjang menyesuaikan dengan lubang yang berbeda-beda, untuk melihat kecenderungannya. Ukuran yang dibuat berbeda pada masing-masing benda uji adalah besar sudut pemotongan profil (Ø) yaitu, $\varnothing_{1}=10^{0}$, $\varnothing_{2}=20^{\circ}, \varnothing_{3}=30^{\circ}, \varnothing_{4}=40^{\circ}, \varnothing_{5}=50^{\circ}, \varnothing_{6}=60^{\circ}$ dan $\varnothing_{7}=0^{0}$ yang kemudian akan diuji lendutannya.

Metode pengumpulan data dilakukan sebagai upaya pembuktian keberadaan data yang dibuat, maka diperlukan data-data yang mendukungnya. Adapun metode yang digunakan dalam penelitian ini adalah:

a. Metode eksperimen

Teknik pengumpulan data dilakukan dengan cara percobaan serta pengujian bahan yang hasilnya nanti diharapkan dapat membantu untuk menyajikan data penelitian.

b. Metode dokumentasi

Teknik pengumpulan data dilakukan dengan cara mengumpulkan data dari dokumen-dokumen atau catatan harian yang ada dari pihak-pihak yang terkait dengan obyek penelitian.

c. Metode literatur atau kepustakaan

Teknik pengumpulan data dilakukan dengan cara mencari literatur atau buku yang berkaitan dengan penelitian.

Tahap-tahap penelitian

a. Masa Persiapan

Pada tahap penelitian ini akan dilakukan pengujian mutu dari profil baja yang akan digunakan sebagai benda uji castellated beam.

b. Preliminary Design.

Merencanakan dimensi balok dan profil yang akan digunakan dan mengubah profil baja WF menjadi profil castella beam.

Benda Uji $1=10^{0}$
Benda Uji $2=20^{0}$

Benda Uji $3=30^{\circ}$

Benda Uji $4=40^{\circ}$

Benda Uji $5=50^{\circ}$

Benda Uji $6=60^{\circ}$

Benda Uji $7=$ Balok utuh (tanpa castella)

c. Pelaksanan Pembuatan Benda Uji

1) Membuat garis patron (garis pola desain) berbentuk castella atau trapesium tanpa alas pada bagian web profil.

2) Menggunakan oxygen + acetylene dengan cutting torch untuk memotong web sesuai garis pola yang sudah dibuat. Di usahakan pemotongan dengan selurus dan sekecil mungkin badan web yang termakan untuk mendapatkan ukuran yang paling mendekati tujuan tinggi web nanti

3) Memisahkan setelah terpotong menjadi 2. Kemudian disambungkan kembali sisi-sisi horizontal dari 2 bagian tersebut. Membalik dan menyesaikan kedua ujungujungnya agar menjadi simetris dan untuk memaksimalkan hasil panjang beam agar sama dengan aslinya. Sistem sambungan las sesuaikan dengan ketebalan web dari beam tersebut.

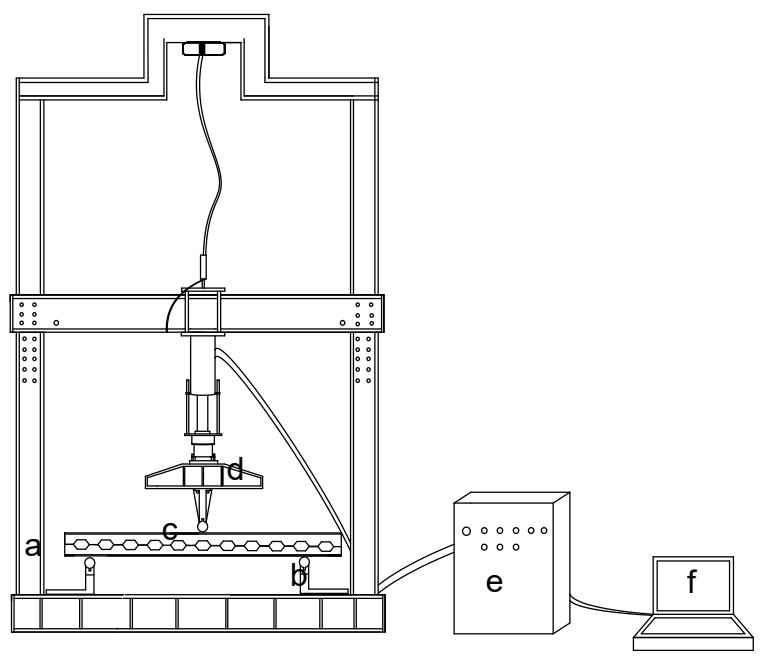

Gambar 4. Setting up pengujian

Berikut ini pada Gambar 5 diberikan daftar alur rencana kerja, untuk memperjelas seluruh rangkaian kegiatan dari studi ini. 


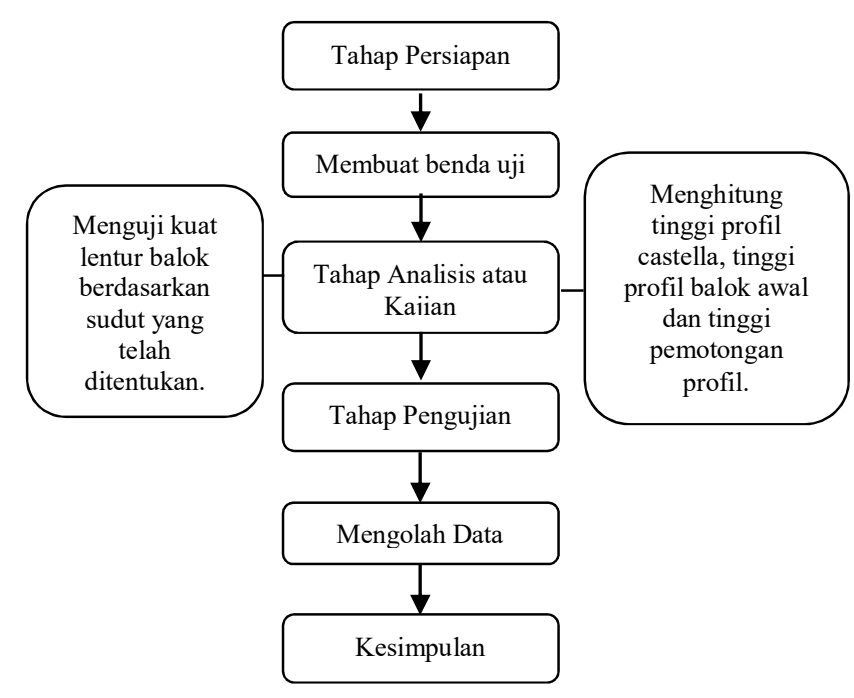

Gambar 5. Alur penelitian

\section{HASIL DAN PEMBAHASAN}

Hasil pengujian uji tarik pada baja WF 198.99.4,5.7 didapat hasil seperti pada gambar 6 berikut ini :

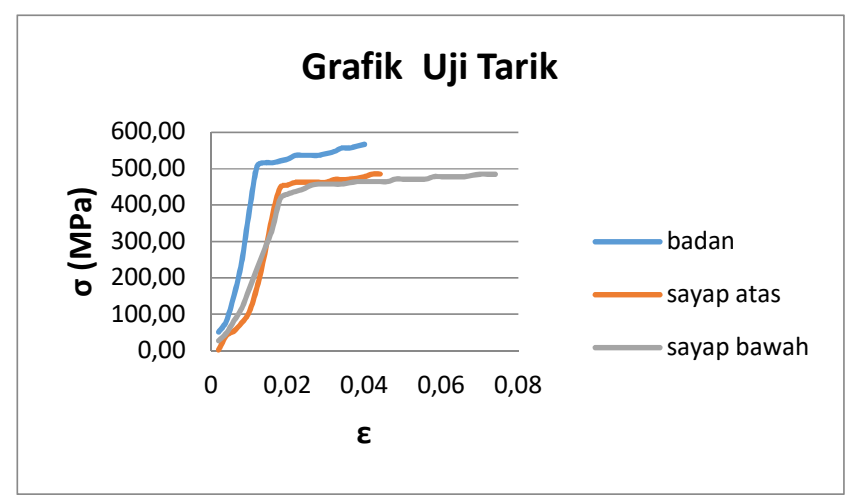

Gambar 6. Grafik Uji Tarik

dari gambar dan data hasil pengujian tarik diatas didapat ratarata yaitu:

$$
\mathrm{f}_{\mathrm{y}}=\frac{384,87+334,43+372,04}{3}=363,77 \approx 364 M P a
$$

Perbandingan Momen dan Tegangan Teori Dengan Momen dan Tegangan Eksperimen Terhadap Besar Sudut Pemotongan Profil (Ø).

Dari hasil pengujian di laboratorium (tes lentur) didapatkan hasil momen seperti pada Tabel 1 berikut ini :

Tabel 1. Hasil Pengujian Momen Lentur

\begin{tabular}{|c|c|c|c|c|c|c|}
\hline \multirow{2}{*}{$\begin{array}{c}\text { Benda } \\
\text { Uji }\end{array}$} & \multirow{2}{*}{ Bentang } & \multirow{2}{*}{$\begin{array}{c}P \\
\text { Eksperime } \\
\mathbf{n}(\mathbf{N})\end{array}$} & \multicolumn{2}{|c|}{ Momen (Nmm) } & \multirow{2}{*}{$\begin{array}{c}\text { rasio } \\
\text { Momen/ } \\
\text { Bentang }\end{array}$} & \multirow{2}{*}{$\begin{array}{c}\text { Persentase } \\
\text { M- } \\
\text { eksperimen } \\
\text { Thd BU } \\
\text { Utuh } \\
\end{array}$} \\
\hline & & & Eksperimen & Teori & & \\
\hline $10^{0}$ & 1320 & 89850 & 29.650 .500 & 73.409 .632 & 0,40 & $46,5 \%$ \\
\hline $20^{\circ}$ & 1420 & 144300 & 51.226 .500 & 73.409 .632 & 0,69 & $80,3 \%$ \\
\hline
\end{tabular}

\begin{tabular}{|c|c|c|c|c|c|c|}
\hline \multirow{2}{*}{$\begin{array}{c}\text { Benda } \\
\text { Uji }\end{array}$} & \multirow{2}{*}{ Bentang } & \multirow{2}{*}{$\begin{array}{c}\text { P } \\
\text { Eksperime } \\
\text { n (N) }\end{array}$} & \multicolumn{2}{|c|}{ Momen (Nmm) } & \multirow{2}{*}{$\begin{array}{c}\text { rasio } \\
\text { Momen/ } \\
\text { Bentang }\end{array}$} & \multirow{2}{*}{$\begin{array}{c}\text { Persentase } \\
\text { M- } \\
\text { eksperimen } \\
\text { Thd BU } \\
\text { Utuh } \\
\end{array}$} \\
\hline & & & Eksperimen & Teori & & \\
\hline $30^{\circ}$ & 1140 & 163300 & 46.540 .500 & 73.409 .632 & 0,63 & $72,9 \%$ \\
\hline $40^{\circ}$ & 1604 & 132350 & 53.072 .350 & 73.409 .632 & 0,72 & $83,2 \%$ \\
\hline $50^{0}$ & 1412 & 156100 & 55.103.300 & 73.409.632 & 0,75 & $86,3 \%$ \\
\hline $60^{\circ}$ & 1295 & 147800 & 47.850 .250 & 73.409 .632 & 0,65 & $75 \%$ \\
\hline Utuh & 1500 & 170200 & 63.825 .000 & 56.656 .600 & 1,12 & $100 \%$ \\
\hline
\end{tabular}

\section{BAGAN SELISIH MOMEN EKSPERIMEN DENGAN MOMEN TEORI}

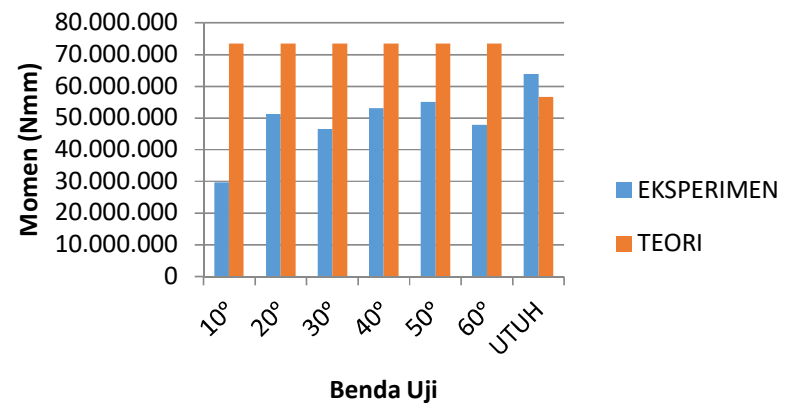

Gambar 7. Grafik Perbandingan Momen Teori Dan Momen Eksperimen

Momen Eksperimen:

dengan:

$$
M=\frac{1}{2} \mathrm{PL}
$$

$\mathrm{M}=$ Momen

$\mathrm{P}=$ Beban terpusat

$\mathrm{L}=$ Panjang benda uji

Pada rumus momen diatas adalah merupakan fungsi dari perkalian antara beban panjang benda uji. Maka semakin besar beban maka semakin besar juga momennya dan semakin besar panjang benda uji maka momennya juga semakin besar.

Pada penelitian ini ada tujuh benda uji balok kastela yang memiliki sudut pemotongan profil (Ø) yang berbeda-beda dan memiliki panjang yang berbeda-beda. Setelah dilakukan pengujian kuat lentur dengan beban terpusat maka didapat beban maksimum balok yang berbeda-beda juga.

Setelah dimasukkan kedalam rumus perhitungan momen maka momen eksperimen yang paling besar adalah benda uji $5\left(\varnothing=50^{\circ}\right)$. Memang beban dan panjang benda uji 5 bukan yang paling besar, namun karna perkalian beban dan panjang benda ujinya maka menghasilkan momen yang paling besar.

Pada benda uji $4\left(\varnothing=40^{\circ}\right)$ bebannya besar namun panjang benda ujinya kecil dibandingkan dengan benda uji $5\left(\varnothing=50^{\circ}\right)$. Pada benda uji $4\left(\varnothing=40^{\circ}\right)$ panjang benda ujinya besar namun 
bebannya kecil dibandingkan dengan benda uji $5\left(\varnothing=50^{\circ}\right)$. Jadi berdasarkan rata-rata beban dan panjang benda uji maka benda uji $5\left(\varnothing=50^{\circ}\right)$ yang memiliki hasil momen yang paling besar.

Momen Teori:

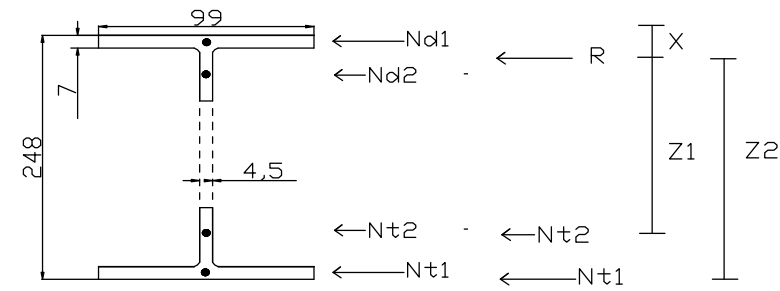

Gambar 8. Dimensi baja

$N d_{1}=N t_{1}=\left(t_{f} x b\right) x f_{y}$

$N d_{2}=N t_{2}=t_{w}\left(\frac{d}{2}-t_{f}-50\right) x f_{y}$

$Z_{1}=d-X-\left(t_{f}+\frac{d t}{2}\right)$

$Z_{2}=d-X-\frac{t_{f}}{2}$

$X=\frac{\Sigma F_{x}}{\Sigma F}=\frac{\left(N d_{1} x \frac{t f}{2}\right)+\left\{N d_{2}\left(t_{f}+\frac{d t}{2}\right\}\right.}{N d_{1}+N d_{2}}$

$$
M_{n}=\left(N t_{1} \times Z_{1}\right)+\left(N t_{2} \times Z_{2}\right)
$$

$$
\begin{array}{ll}
\mathrm{M} & =\text { Momen } \\
\mathrm{b} & =\text { Lebar profil } \\
\mathrm{f}_{\mathrm{y}} & =\text { Mutu } \\
\text { Bajat }_{\mathrm{f}} & =\text { tebal sayap profil } \\
\mathrm{Z} & =\text { Modulus plastis } \\
\mathrm{t}_{\mathrm{w}} & =\text { tebal badan profil } \\
\mathrm{h} & =\text { Tinggi profil }
\end{array}
$$

Untuk momen teori setiap benda uji sama karna memiliki dimensi yang sama. Jadi perubahan besar sudut potongan profil $(\varnothing)$ tidak berpengaruh.

Jadi berdasarkan hasil pengujian di laboratorium dan Gambar 4.2 diatas didapat bahwa semakin besar sudut pemotongan profil (Ø) maka semakin besar momen yang

\begin{tabular}{|c|c|c|c|c|c|c|}
\hline \multirow{2}{*}{$\begin{array}{c}\text { Benda } \\
\text { Uji }\end{array}$} & \multirow{2}{*}{ Bentang } & \multirow{2}{*}{$\begin{array}{c}\text { P } \\
\text { Eksperime } \\
\text { n (N) }\end{array}$} & \multicolumn{2}{|c|}{ Momen (Nmm) } & \multirow{2}{*}{$\begin{array}{c}\text { rasio } \\
\text { Momen/ } \\
\text { Bentang }\end{array}$} & \multirow{2}{*}{$\begin{array}{c}\text { Persentase } \\
\text { M- } \\
\text { eksperimen } \\
\text { Thd BU } \\
\text { Utuh } \\
\end{array}$} \\
\hline & & & Eksperimen & Teori & & \\
\hline $10^{0}$ & 1320 & 89850 & 147,63 & 365,5 & 0,57 & $27,8 \%$ \\
\hline $20^{\circ}$ & 1420 & 144300 & 255,05 & 365,5 & 0,70 & $48,1 \%$ \\
\hline
\end{tabular}
terjadi pada balok tersebut. Ini disebabkan karna semakin

\begin{tabular}{|c|c|c|c|c|c|c|}
\hline \multirow{2}{*}{$\begin{array}{c}\text { Benda } \\
\text { Uji }\end{array}$} & \multirow{2}{*}{ Bentang } & \multirow{2}{*}{$\begin{array}{c}P \\
\text { Eksperime } \\
n(N)\end{array}$} & \multicolumn{2}{|c|}{ Momen (Nmm) } & \multirow{2}{*}{$\begin{array}{c}\text { rasio } \\
\text { Momen/ } \\
\text { Bentang }\end{array}$} & \multirow{2}{*}{\begin{tabular}{|c|} 
Persentase \\
M- \\
eksperimen \\
Thd BU \\
Utuh \\
\end{tabular}} \\
\hline & & & Eksperimen & Teori & & \\
\hline $30^{\circ}$ & 1140 & 163300 & 231,72 & 365,5 & 0,63 & $43,7 \%$ \\
\hline $40^{\circ}$ & 1604 & 132350 & 264,24 & 365,5 & 0,72 & $49,8 \%$ \\
\hline $50^{0}$ & 1412 & 156100 & 274,35 & 365,5 & 0,75 & $51,7 \%$ \\
\hline $60^{\circ}$ & 1295 & 147800 & 238,24 & 365,5 & 0,65 & $44,9 \%$ \\
\hline Utuh & 1500 & 170200 & 530,63 & 610,3 & 0,87 & $100 \%$ \\
\hline
\end{tabular}
besar sudut pemotongan profil maka semakin kecil lubang pada balok kastela tersebut. Sehingga balok yang kehilangan lubang terkecil dapat menahan momen yang lebih besar.

Dari hasil perhitungan momen maka didapatkan hasil tegangan seperti pada Tabel 2 berikut ini :

Tabel 2. Hasil Pengujian Tegangan Lentur

\section{BAGAN SELISIH TEGANGAN EKSPERIMEN DENGAN TEGANGAN TEORI}

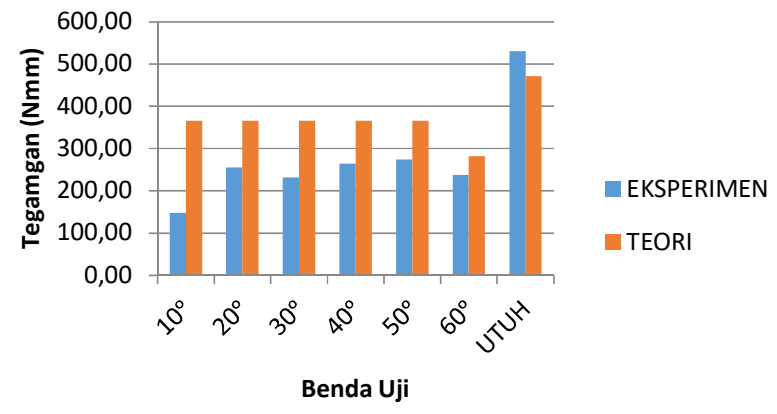

Gambar 9. Grafik Perbandingan Tegangan Teori Dan Tegangan Eksperimen

Rumus tegangan :

$$
\sigma=\frac{M \cdot Y}{I} \quad Y=\frac{1}{2} h
$$

Jadi tegangan adalah :

$$
\sigma=\frac{M \cdot \frac{h}{2}}{I}
$$

Keterangan :

$$
\begin{aligned}
& \sigma=\text { Tegangan } \\
& \mathrm{M}=\text { Momen } \\
& \mathrm{h}=\text { Tinggi profil } \\
& \mathrm{I}=\text { Momen inersia }
\end{aligned}
$$

Pada penelitian ini tinggi profil setiap benda uji sama dan untuk momen inersia juga sama. Momen inersianya sama karna pada perhitungannya tidak berpengaruh terhadap besar sudut pemotongan profil, jadi setiap benda uji walaupun sudut pemotongannya berbeda-beda maka momen inersianya tetap.

Seperti pada perhitungan sebelumnya momen setiap benda uji berbeda-beda. Jadi tegangan yang dihasilkan juga berbeda-beda walaupun tinggi profil dan momen inersianya sama.

Semakin besar momennya semakin besar juga tegangan yang dihasilkan. Momen yang paling besar terdapat pada benda $5\left(\emptyset=50^{\circ}\right)$. Jadi dapat disimpulkan tegangan yang 
paling besar juga pada benda uji $5\left(\varnothing=50^{\circ}\right)$. Maka rasio yang paling besar juga pada benda uji $5\left(\varnothing=50^{\circ}\right)$.

Dari Gambar 9 Grafik Perbandingan Momen Teori Dan Momen Eksperimen dan Gambar 7 Grafik Perbandigan Tegangan Teori Dan Tegangan Eksperimen didapat bahwa momen runtuh dan tegangan runtuh hasil perhitungan teori lebih besar dari momen runtuh dan tegangan runtuh hasil eksperimen, kecuali pada benda uji utuh. Sedangkan pada suatu penelitian seharusnya hasil eksperimen harus lebih besar dari teori hasil perhitungan teori.

Permasalahan diatas kemungkinan penyebab terjadinya kegagalan pada penelitian ini adalah kurang tepatnya penempatan beban. Pada penelitian ini penempatan beban diletakkan pada bagian penampang balok yang berlubang. Pada penampang balok yang berlubang gaya lintang pembebanan tidak bisa disalurkan secara merata karena adanya lubang, sehingga saat runtuh momen belum sampai mencapai momen nominal, dan tegangannya belum mencapai tegangan ijin, sehingga kerusakannya bukan karena kerusakan lentur, melainkan rusak geser.

Berdasarkan Tabel 2 Hasil Pengujian Tegangan Lentur didapat bahwa dengan adanya penambahan besar sudut pemotongan profil maka tegangan runtuh yang diterima oleh balok kastela semakin kecil. Hal ini disebabkan karena pada bagian yang berlubang pada balok kastela memiliki penampang yang kecil, sehingga pada saat pengujian balok tersebut sudah runtuh sebelum menerima tegangan yang besar. Jadi untuk aplikasi di lapangan, sebagai contoh sebaiknya gording jangan di letakkan pada bagian balok kastela yang berlubang, melainkan pada bagian yang utuh.

Tabel 3. Hasil Pengujian Lendutan Pada P maksimal

\begin{tabular}{|c|c|c|c|c|c|}
\hline $\begin{array}{c}\text { Benda } \\
\text { Uji }\end{array}$ & $\begin{array}{c}\text { Bentang } \\
(\mathbf{m m})\end{array}$ & $\begin{array}{c}\text { P Maks } \\
\text { Eksperimen } \\
(\mathbf{N})\end{array}$ & $\begin{array}{c}\text { Lendutan } \\
\text { Eksperimen } \\
\mathbf{( m m )}\end{array}$ & $\begin{array}{c}\text { Rasio } \\
\text { Lendutan } \\
\text { (Bentang }\end{array}$ & $\begin{array}{c}\text { Lendutan } \\
\text { Ijin }\end{array}$ \\
\hline $10^{\circ}$ & 1320 & 89.850 & 1,58 & 0,0012 & $\frac{1}{11.000} L$ \\
\hline $20^{\circ}$ & 1420 & 144.3000 & 3,32 & 0,0023 & $\frac{1}{6.173} L$ \\
\hline $30^{\circ}$ & 1140 & 163.300 & 2,87 & 0,0025 & $\frac{1}{4.560} L$ \\
\hline $40^{\circ}$ & 1604 & 132.350 & 3,58 & 0,0022 & $\frac{1}{7.290} L$ \\
\hline $\mathbf{5 0}$ & $\mathbf{1 4 1 2}$ & $\mathbf{1 5 6 . 1 0 0}$ & $\mathbf{3 , 5 9}$ & $\mathbf{0 , 0 0 2 5}$ & $\frac{1}{5.648} L$ \\
\hline $60^{\circ}$ & 1295 & 147.800 & 2,74 & 0,0021 & $\frac{1}{6.166} L$ \\
\hline Utuh & 1500 & 170.200 & 6,45 & 0,0043 & $\frac{1}{3.488} L$ \\
\hline
\end{tabular}

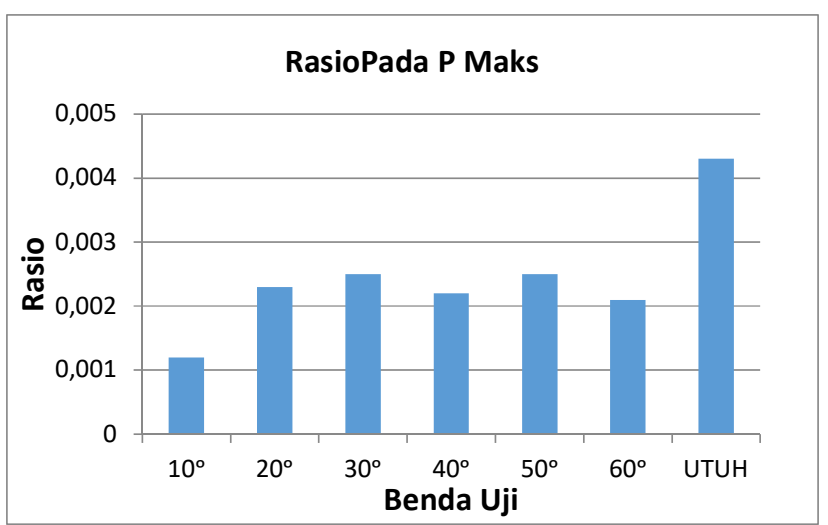

Gambar 10. Grafik Rasio Lendutan Terhadap Bentang Pada Beban Maksimal

Tabel 4. Hasil Pengujian Lendutan Pada P yang sama

\begin{tabular}{|c|c|c|c|c|}
\hline $\begin{array}{c}\text { Benda } \\
\text { Uji }\end{array}$ & $\begin{array}{c}\text { Bentang } \\
(\mathbf{m m})\end{array}$ & $\begin{array}{c}\text { Lendutan } \\
\text { Eksperimen } \\
\text { (mm) }\end{array}$ & $\begin{array}{c}\text { Rasio } \\
\text { Lendutan } \\
\text { /Bentang }\end{array}$ & $\begin{array}{c}\text { Lendutan } \\
\text { Ijin }\end{array}$ \\
\hline $10^{0}$ & 1320 & 1,05 & 0,00080 & $\frac{1}{16.500} L$ \\
\hline $20^{0}$ & 1420 & 1,19 & 0,00084 & $\frac{1}{16.904} L$ \\
\hline $30^{0}$ & 1140 & 0,66 & 0,00058 & $\frac{1}{19.655} L$ \\
\hline $40^{0}$ & 1604 & 1,01 & 0,00063 & $\frac{1}{25.460} L$ \\
\hline $\mathbf{5 0}^{\mathbf{0}}$ & $\mathbf{1 4 1 2}$ & $\mathbf{1 , 2 3}$ & $\mathbf{0 , 0 0 0 8 7}$ & $\frac{1}{16.229} L$ \\
\hline $60^{0}$ & 1295 & 0,94 & 0,00073 & $\frac{1}{17.739} L$ \\
\hline $\mathrm{UTU}$ & 1500 & 1,46 & 0,00097 & $\frac{1}{15.463} L$ \\
\hline $\mathrm{H}$ & & & & \\
\hline
\end{tabular}

Rasio Pada P Yang Sama (50000 N)

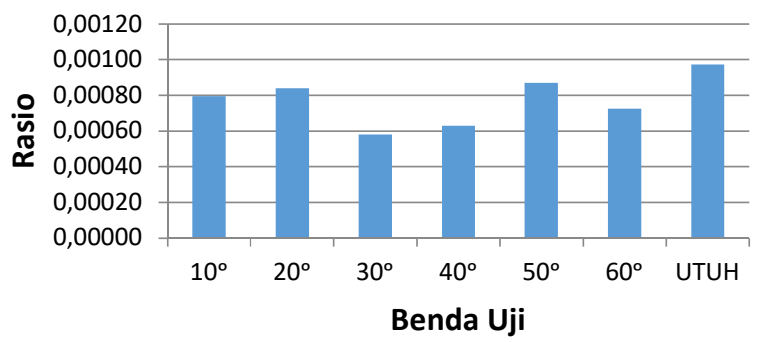

Gambar 11. Grafik Rasio Lendutan Terhadap Bentang Pada Beban $50 \mathrm{kN}$

Apabila kita analisis ulang, berdasarkan Gambar 11 ada kecenderungan yang tampak pada rasio antara lendutan terhadap bentang. Berdasarkan Gambar 11 Pada BU6 $\left(60^{\circ}\right)$ sampai BU3 $\left(30^{\circ}\right)$ ada penurunan untuk rasio lendutan, hal ini disebabkan karna semakin besar sudut pemotongan profil maka momen inersianya semakin besar sehingga lendutannya semakin kecil, tetapi pada BU5 $\left(50^{\circ}\right)$ ada lonjakan yang besar hal ini mungkin di sebabkan adanya faktor kesalahan pada 
saat pengujian. Sedangkan pada BU1 dan BU2 apabila dihubungakan dengan Grafik 4.10 pada BU1 dan BU2 angka pergoyangan (buckling) sangat besar, ini berarti bahwa ada kemungkinan pada saat pengujian, pada BU1 dan BU2 sebelum mengalami rusak lentur, benda uji tersebut sudah runtuh terlebih dahulu karena buckling, dan apabila dihubungkan pada Tabel 1 dan Tabel 2 akibat kerusakan buckling sebelum terjadi kerusakan lentur sehingga pada BU1 dan BU2 hanya dapat menahan momen yang kecil dan menerima tegangan yang kecil pula, sehingga sebelum mencapai kekuatan lentur maksimal balok tersebut sudah rusak runtuh lebih dulu.

Berdasarkan analisis tersebut, didapat bahwa untuk keamanan indikasi lentur awal, besar sudut pemotongan profil adalah $50^{\circ}$ sampai $60^{\circ}$. Dengan adanya penambahan besar sudut pemotongan profil tentu ada resiko indikasi untuk terjadi buckling. Untuk menganalisis bahwa ada indiksi terjadi buckling pada pengujian, Dari pembacaan dial 5 didapat data untuk pengujian sebagai berikut :

Tabel 5. Tabel hasil Pengujian Buckling Pada Beban Maksimal

\begin{tabular}{|c|c|c|}
\hline BENDA UJI & $\begin{array}{c}\text { P } \\
\text { Maks (kN) }\end{array}$ & $\begin{array}{c}\text { Pergoyangan } \\
(\mathbf{m m})\end{array}$ \\
\hline $10^{0}$ & 90 & 4,5 \\
\hline $20^{0}$ & 140 & 3,92 \\
\hline $30^{\circ}$ & 160 & 4,88 \\
\hline $40^{\circ}$ & 130 & 5,12 \\
\hline $\mathbf{5 0}^{\mathbf{0}}$ & $\mathbf{1 5 5}$ & $\mathbf{6 , 1 3}$ \\
\hline $60^{0}$ & 145 & 5,09 \\
\hline Utuh & 170 & 0,97 \\
\hline
\end{tabular}

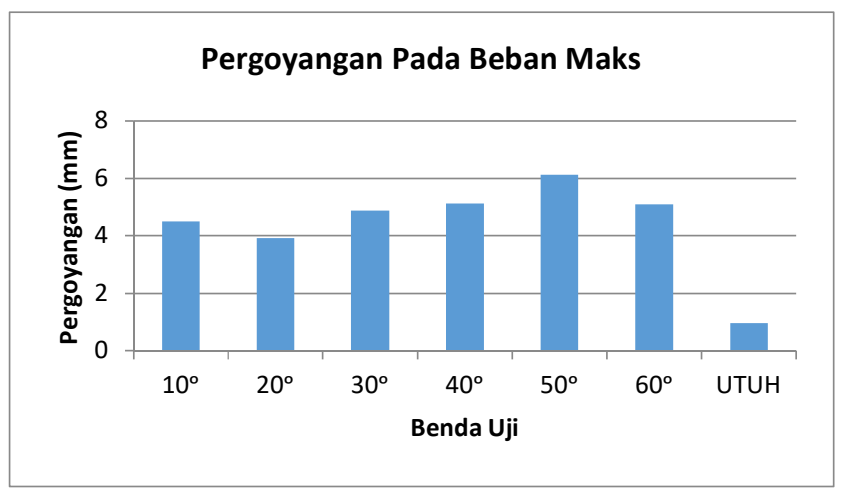

Gambar 12. Grafik Buckling Pada Beban Maksimal

Tabel 6. Tabel hasil Pengujian Buckling Pada Beban 50kN

\begin{tabular}{|c|c|c|}
\hline BENDA UJI & $\begin{array}{c}\mathbf{P} \\
\mathbf{5 0} \mathbf{~ k N}\end{array}$ & $\begin{array}{c}\text { Pergoyangan } \\
(\mathbf{m m})\end{array}$ \\
\hline $\mathbf{1 0}^{\mathbf{0}}$ & $\mathbf{5 0}$ & $\mathbf{1 , 5 9}$ \\
\hline $\mathbf{2 0}^{\mathbf{0}}$ & $\mathbf{5 0}$ & $\mathbf{1 , 6 6}$ \\
\hline $30^{\circ}$ & 50 & 1,44 \\
\hline
\end{tabular}

\begin{tabular}{|c|c|c|}
\hline BENDA UJI & $\begin{array}{c}\text { P } \\
\mathbf{5 0} \mathbf{~ k N}\end{array}$ & $\begin{array}{c}\text { Pergoyangan } \\
(\mathbf{m m})\end{array}$ \\
\hline $40^{0}$ & 50 & 1,32 \\
\hline $50^{0}$ & 50 & 0,98 \\
\hline $60^{0}$ & 50 & 0,83 \\
\hline UTUH & 50 & 0,07 \\
\hline
\end{tabular}

\section{Pergoyangan Pada Beban Yang Sama (50kN)}

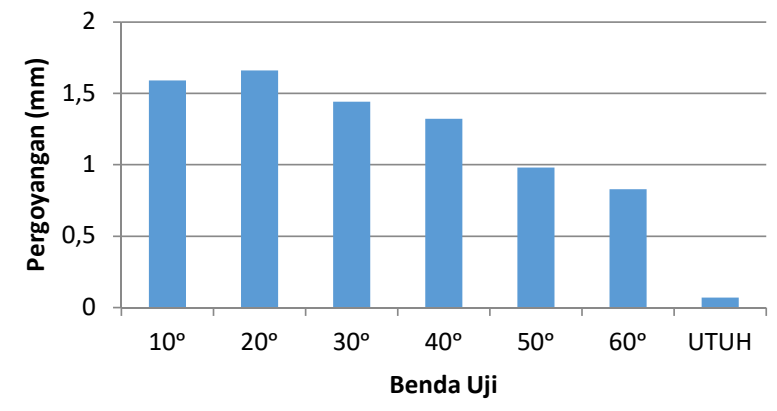

Gambar 13. Grafik Buckling Pada Beban 50 kN

Berdasarkan Gambar 13 didapat bahwa ada kecenderugan untuk nilai pergoyangan (buckling) pada saat pengujian. Dari analisis tersebut didapat bahwa dengan adanya penambahan besar sudut pemotongan profil, maka semakin besar nilai pergoyangannya. Ini berarti bahwa dengan adanya penambahan besar sudut pemotongan profil ada indikasi buckling pada balok kastela. Berdasarkan data hasil pengujian dan hasil analisisi diatas didapat bahwa untuk keamanan maka besar sudut pemotongan profil sekitar $50^{\circ}$ sampai $60^{\circ}$.
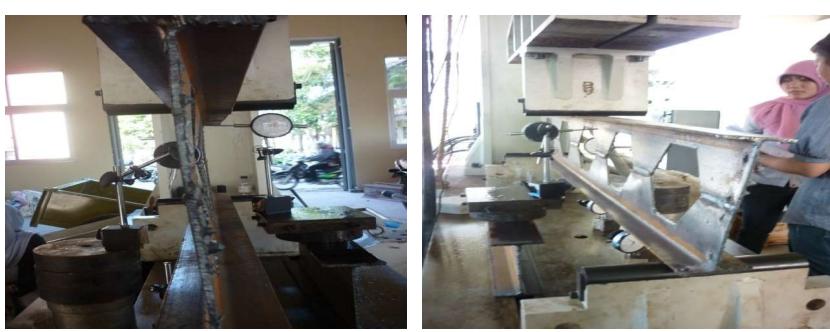

Gambar 14. Kerusakan buckling

Dari uraian analisisi diatas didapat bahwa untuk penempatan pembebanan di bagian penampang yang berlubang, untuk menghindari indikasi trjadinya lentur awal dan indikasi terjanya buckling dianjurkan besar sudut pemotongan profil tidak lebih dari $40^{\circ}$ sebelum dibuat balok kastela, dan apabila dihubungakan dengan Tabel 4.2 dan 4.3 pada benda uji tersebut juga masih bisa menahan momen yang besar dan menerima tegangan yang besar pula. 


\section{KESIMPULAN}

Hasil penelitian menunjukkan bahwa jika ditinjau dari momen, tegangan, lendutan, dan pergoyangan (buckling) maka besar sudut pemotongan profil mulai dari $50^{\circ}$ adalah profil yang memenuhi syarat. Akan tetapi pada keadaan ini lemah terhadap gaya geser.

Hasil penelitian menunjukkan bahwa jika besar sudut pemotongan profil lebih dari $40^{\circ}$, ada indikasi terjadi rusak geser pada penampang balok yang berlubang. Akan tetapi pada besar sudut pemotongan profil kurang dari $40^{\circ}$ mengalami pergoyangan (buckling) yang paling besar, dan momen, tegangan serta lendutan yang terjadi paling kecil.

\section{DAFTAR PUSTAKA}

Amon, Rene dan Knobloch Atanu Mazumder, Bruce.1999."Perencanaan Konstruksi Baja Untuk Insinyur Dan Arsitek 2.Jakarta:PT. AKA

Dougherty, B.K. Castellated beams: Astate of the art report. Journal of the South African lnstitution of Civil Engineers, 35:2, 2nd Quarter, pp 12-20. 1993.

Hosain.. M.U., and Spiers. W.G. Experiments on castellated steel beams. J. American Welding Society, Welding Research Supplement, 52:8, 329S-342S. 1973.

Knowles, P.R. Castellated beams. Proc. Institution of Civil Engineers, Part l, Vol. 90, pp 521-536. 1991

L. Amayreh and M. P. Saka "Department of Civil Engineering, University of Bahrain". Failure load prediction of castellated beamsUsing artificial neural networks. 2005.

Nethercot.. D.A., and Kerdal.. O. Laterai-torsional buckling of castellated beams Struct. Engr 60B:3, 53-61 . 1983

Sylvya Anggraini.2008."Modifikasi Perencanaan Hotel Bahtera Balikpapan Menggunakan Hexagonal Castellated Beam". ITS Surabaya : Skripsi (tidak diterbitkan).

Suprapto. 2005. "Panduan Uji Bahan Bangunan". Direktorat Jendral Pendidikan Tinggi Universitas Negeri Surabaya.

Suprapto. 2005. "Metode Eksperimen Struktur". Direktorat Jendral Pendidikan Tinggi Universitas Negeri Surabaya.

Tim Penyusun.2006. "Panduan penulisan dan Penilaian Skripsi Universitas Negeri Surabaya. Surabaya". Universitas Negeri Surabaya. 